\title{
The Effect of Employee Competencies and Discipline on the Performance of State Civil Apparatus at Wewiku District Office, Malaka Regency
}

\author{
Yohanes Lau ${ }^{1} \quad$ Frans Gana $^{2} \quad$ M.N.B.C. Neolaka ${ }^{3}$ \\ Master's Program in Administrative Sciences, Postgraduate Program, Universitas Nusa Cendana Kupang, East \\ Nusa Tenggara, Indonesia
}

\begin{abstract}
The ability of a nation is determined by the capability of the bureaucratic apparatus in carrying out its duties and functions as a professional and accountable public servant and can be measured from performance achievements. The purpose of this study was to provide input to the government of Malaka regency regarding the employee competencies and discipline and its influence of the performance on officers at Wewiku district, Malaka regency. There are still problems with employee performance in Wewiku district, such as the low quality of work and the limited reliability of work. The population of this research is all State Civil Apparatus working in Wewiku district, Malaka regency. The State Civil Apparatus living in Wewiku District, Malaka Regency, work at the Wewiku District Office, and the others are Village Secretary for 12 villages in Wewiku district, so the total is 33 people. The results of the statistical analysis show that the correlation coefficient $r$ between the competence and the performance variable is 0.7252 . If connected with table 3.2 , the value is in the interval of 0.60 to 0.799 , meaning that the influence of competence on the performance of the state civil apparatus in Wewiku district, Malaka regency district is stron. Also, the analysis of the correlation coefficient $r$ between the variable of employees discipline and performance is 0.6487 . If connected with table 3.2 , the value is in the interval of 0.60 to 0.799 , meaning that the effect of discipline on the performance of the state civil apparatus in Wewiku district, Malaka regency is strong. Moreover, the calculation results used the regression equation for two predictors: If $Y=a+b_{1} X_{1}+b_{2} X_{2}$, the Adjusted $\mathrm{R}$ Square value of 0.60757 multiplied by $100 \%$ will result in $60.759 \%$, meaning that the influence of competence $\left(\mathrm{X}_{1}\right)$ and discipline $\left(\mathrm{X}_{2}\right)$ on the performance of state civil apparatus in Wewiku district is quite significant. Therefore, the head of Wewiku district and Malaka regency is recommended to improve further the competence and discipline of employees by conducting further studies for civil servants, registering employees in training, and fostering employee attitudes so that they have a more positive effect on the performance of the state civil apparatus. Keywords: Performance, Wewiku District, Competence, Discipline, Malaka Regency
\end{abstract}

DOI: $10.7176 /$ PPAR/10-9-01

Publication date:September $30^{\text {th }} 2020$

\section{BACKGROUNDS}

One of the abilities of a nation is determined by the capability of the bureaucratic apparatus in carrying out its duties and functions, namely as a professional and accountable public servant. A condition showing that the public can be served well and satisfactorily by the bureaucratic apparatus will automatically make the bureaucratic apparatus stand at their position as a public servant.

In order to implement the ideals of the nation and realize the goals of the state, it is necessary to build a State Civil Apparatus that has integrity, is professional, neutral, free from political interference, free from practices of corruption, collusion and nepotism, and can provide public services for the community and can carry out a role as an element of glue for national unity and integrity based on Pancasila and the 1945 Constitution of the Republic of Indonesia(Source: The 1945 Constitution No. 5 of 2014)

Excellent and satisfying service will have an impact on the performance of the bureaucratic apparatus in accordance with the expectations of the community, which will eventually result in an upbeat assessment of the bureaucratic apparatus. This is the reason a country or region has a progress in terms of bureaucratic services to its citizens to create a clean, accountable and transparent bureaucracy. The bureaucracy is able to support the realization of public welfare through its function and role as public servants. This task is the responsibility of the bureaucratic apparatus, and the existence of civil servants is the keyword for the sustainability of a government, especially in public services. The significant role played by civil servants is the reason why society needs them and has a strategic position in the life of the state and society.

In the government system, civil servants become a symbol of the ongoing system and identity of governance to run correctly and cleanly. In connection with the duties and functions of the State Civil Apparatus, civil servants must work following their competence and be followed by high discipline so that the performance of the State Civil Apparatus can be optimal.

Performance can be identified and measured if individuals or groups of civil servants already have a standard criterion for measuring success in the organization. It cannot be denied that, in Wewiku district, Malaka regency, 
there are still employee performance problems which indicate the low quality of work and the limited work reliability. In connection with existing problems, researchers want to know the state of employee competences and discipline and their impact on employee performance.

In terms of realizing the State Civil Apparatus as a part of bureaucratic reform, it is necessary to establish the State Civil Apparatus as a profession that should manage and develop themselve and is obliged to be accountable for their performance and apply the principle of merit in the implementation of the management of the State Civil Apparatus. In connection with the mandate of the State Civil Apparatus Law, the State Civil Apparatus in Wewiku district, Malaka regency is expected to have proper competence and high discipline to realize their performance.

The State Civil Apparatus assigned by the Regent of Malaka in Wewiku district includes village secretaries according to educational qualifications, high school graduates in a higher percentage of $42.43 \%$, associate's degree and bachelor's degree is $21.21 \%$, and junior high schools graduates by $15.15 \%$ of the 33 employees (source: Head of Wewiku district, Malaka regency, 2019).

Based on the description of the situation and disciplinary problems on employee performance and service to the community in Weliman district, it is necessary to conduct a study entitled: "The Influence of Employee Competences and Discipline on the Performance of State Civil Apparatus in the Office of the Head of Wewiku District, Malaka Regency".

The objectives of this study were; (1) To provide input to the government of Malaka District regarding the employee competences and discipline and its influence on the performance in Wewiku District, Malaka Regency; (2) To contribute research results to other parties to be studied and used as a reference by other researchers who study the influence of competence and discipline on employee performance

\section{LITERATURE REVIEWS}

Competence is defined as "ability; capability; cleverness or skill at doing something." (Drafting Team of National Education Department, 2001, p. 187). Therefore, employee competences can be defined as the ability of individuals who are members of an institution to carry out activities that become institutional duties and functions as well as tasks handled individually and controlled based on the organizational system.

Generally, Spencer and Spencer grouped competency into 6 (six) categories to achieve high performance for both technicians and professionals and leaders: "(1) Competence to have achievement and act, (2) Competence to serve, (3) Competence to lead, (4) Competence to manage, (5) Competence to think, (6) Effective personality competence" (Spencer and Spencer in Yuniarsih and Suwatno, 2008, p. 25).

Points 1 to 6 can be described as follows: Performance competencies and actions; Actually, this competence is based on: Achievement orientation; emphasizes on better work results, competes beyond standards and performs well. Attitudes that demonstrate achievement are working to exceed standards set by management, determining and acting to achieve challenging goals for oneself and others, taking the initiative to always seek information and having conceptual thinking.

Discipline is defined as obedience to the rules of conduct. Discipline comes from the Latin word diciplina, which means "training or education of politeness and spirituality and character development" (Moekijat, 1999, p. 139). The meaning of discipline emphasizes on helping employees to develop a proper attitude towards their work.

Discipline is a prerequisite for the formation of disciplined attitudes, behaviours and an order of life that will make it easier for employees to work. There are 2 (two) forms of discipline: 1). Preventive discipline is an effort to mobilize employees to follow and comply with work guidelines, the rules that have been outlined by the organization (institution). The primary goal is to motivate employees to self-discipline. With a preventive way, employees can maintain themselves against the regulations of the organization or institution. 2). Corrective discipline is an effort to mobilize employees to unite regulations and move them to comply with the rules in accordance with the applicable guidelines in the organization (institution). In corrective discipline, employees who violate discipline need to be given sanctions in accordance with applicable regulations". (Mangkunegara, 2005, p. 129).

In terms of supporting the above statement, it is stated that there are two very dominant work disciplines, namely "discipline in time, and discipline in terms of work or actions." (Moenir, 2008, p. 96). The two types of discipline are inseparable and influence each other. Time discipline without work discipline has no results in accordance with administrative regulations. On the other hand, work discipline without time discipline is useless.

It is further stated that there are three work disciplines: 1). Preventive discipline is an activity carried out to encourage employee to follow various standards and rules; so that abuse can be prevented. 2). Corrective discipline is an activity taken to deal with violations of rules that try to avoid further violations. Corrective activity is often a form of punishment and is called disciplinary action. 3). Progressive discipline is the activity of providing harsher penalties for repeated offences. The aim of this progressive discipline is for employees to take corrective actions before getting a more severe sentence. (Handoko, 1994, p. 208).

Performance is "a description of the achievement level of the implementation of an activity, program, policy in realizing the goals, objectives, mission, vision and organization" (state administrative agency in Pasolong, 2008, 
p. 176). It is also said that performance is a description of the level of achievement of the implementation of an activity or policy program in realizing the goals, objectives, mission and vision of the organization as stated in (public) strategic planning" (Mahsun, 2006, p. 25).

Factors that affect performance are: (1) ability, (2) willingness, (3) energy, (4) technology, (5) compensation, (6) clarity of purpose, and (7) security (extracted from Pasolong, 2008, p. 188-189). There is a same meaning as said that the factors which influence performance are "(1) Individual personnel factors, including knowledge, skills, abilities, self-confidence, motivation and commitment possessed by each individual.; (2) Leadership factors include quality in providing encouragement, enthusiasm, direction and support provided by managers and team leaders; (3) Team factors include the quality of support with enthusiasm given by colleagues in a team, trust in fellow team members, cohesiveness and closeness of team members; (4) System factors include work systems, work facilities, or infrastructure provided by the organization and organizational performance culture; (4) Contextual (Situational) factors include pressure and changes in the external and internal environment". (Mahmudi, 2005, P. 21).

\section{METHODOLOGY}

This writing was done according to a descriptive model. The purpose of descriptive research was to describe the influence of employee competences and work discipline on the performance of State Civil Apparatus at Wewiku district office, Malaka Regency. The research approach used was quantitative; namely, the research data was processed to calculate the correlation coefficient $r$ to determine the level of influence of competence and discipline variable on the performance of State Civil Apparatus. In connection with the use of a quantitative approach, the research instrument used was a questionnaire. The questionnaire model used was a Likert scale with five alternative answers, each of which was given a weighted score based on the gradation level of the alternative answers, starting from the most positive to the most negative. The population of this research is all State Civil Apparatus working in Wewiku district, Malaka regency. The State Civil Apparatus living in Wewiku district, Malaka regency, work at Wewiku district office, and the others are Village Secretary working in 12 villages in Wewiku district, so the total is 33 people. The study was conducted on three variables, consisting of 2 independent variables or influence variables and one dependent variable or affected variable. The independent variable or influence variable (variable $\mathrm{X}$ ) consisted of an employee competence (X1) and discipline (X2) variable. The dependent variable is employee performance (Y). The instrument used in this study was a questionnaire. The questionnaire model used was a Likert scale with 5 alternative answers: Strongly Agree (SA) with a score of 5, Agree (A) with a score of 4, Doubt (D) with a score of 3, Disagree (D) with a score of 2, Strongly Disagree (SS) with a score of 1 . The answer score can be weighted for positive questionnaire statements. As for negative statements, the respondent's answer scores can be reversed as follows: Strongly Agree (SA) with a score of 1, Agree (A) with a score of 2, Doubt (D) with a score of 3, Disagree (D) with a score of 4 , Strongly Disagree (SS) with a score of 5.

\section{RESULTS AND DISCUSSION}

Data Analysis and Interpretation of Employee Competence Variable

\begin{tabular}{|c|c|c|c|c|c|c|c|}
\hline \multirow[t]{2}{*}{ Dimensions } & \multicolumn{5}{|c|}{ Indicator } & \multirow[t]{2}{*}{ Total } & \multirow[t]{2}{*}{ Mean } \\
\hline & 1 & 2 & 3 & 4 & 5 & & \\
\hline Settings & 3.7 & 3.36 & 3.64 & 3.73 & 3.79 & 18.22 & 3.64 \\
\hline Skills & 3.55 & 2.79 & 2.7 & 3.67 & 3.36 & 16.07 & 3.21 \\
\hline Attitude & 3.55 & 3.3 & 3.52 & 3.85 & 3.73 & 17.95 & 3.59 \\
\hline Mean Variabel & & & & & & & 3.48 \\
\hline
\end{tabular}

The state of the employee's competence variable can be described by the mean score of 3.48. If connected with table 3.3, the score is in the interval of 2.51-3.50 with the criteria of being quite good and functioning quite well. The competence variable condition can be interpreted that the state civil apparatus' competence is categorized as quite useful and functions quite well in carrying out their duties as a state civil apparatus.

Three dimensions in each competency variable are as follows: knowledge dimension with a mean score of 3.64 , and the attitude dimension with a mean score of 3.21 which, if referred to in table 3.3 , are in the interval 3.51- 4.50. Thus, it is categorized as good condition and functioning correctly. Therefore, it can be interpreted that the state of knowledge and attitude of the state civil servants in Wewiku district, Malaka regency is categorized as good and function well in carrying out their duties. The skill dimension in this variable got a mean score of 3.59, which according to table 3.3 is in the interval 2.51-3.50, meaning that the state of civil service skills in Wewiku district, Malaka regency is categorized as quite reasonable and functions quite well in carrying out their duties. 
Data Analysis and Interpretation of Employee Discipline Variables

\begin{tabular}{|l|r|r|r|r|r|r|r|}
\hline \multirow{2}{*}{ Dimensions } & \multicolumn{9}{|c|}{ Total } & \multirow{2}{*}{ Mean } \\
\cline { 2 - 7 } & 1 & 2 & 3 & 4 & 5 & & \\
\hline Work motivation & 3.42 & 3.45 & 2.79 & 3.39 & 3.58 & 16.63 & 3.33 \\
\hline Spirit at work & 3.24 & 3.88 & 3.39 & 2.45 & 3.39 & 16.35 & 3.27 \\
\hline Leadership Supervisor & 3.67 & 3.36 & 2.58 & 3.39 & 3.85 & 16.85 & 3.37 \\
\hline Mean Variabel & \multicolumn{9}{|c|}{} & & 3.32 \\
\hline
\end{tabular}

The state of the employee discipline variable can be described by the mean score of 3.32 which, if connected to table 3.3, means that the score is in the interval 2.51-3.50 with the criteria for a reasonably good condition and functioning quite well. The condition of these disciplinary variables can be interpreted that the state of the discipline of the state civil apparatus is categorized as quite useful and functions quite well in carrying out their duties as a state civil apparatus.

Three dimensions in each discipline variable are the dimension of work motivation with a mean score of 3.37, the dimension of spirit at work with a mean score of 3.27, and the dimension of leadership supervision of 3.33 which, if referred to in table 3.3, is in the interval $2.51-3.50$, with the criteria of a reasonably good condition and functioning adequately. Data Analysis and Interpretation of Employee Performance Variables

\begin{tabular}{|c|c|c|c|c|c|c|c|}
\hline \multirow[t]{2}{*}{ Dimensions } & \multicolumn{5}{|c|}{ Indicator } & \multirow[t]{2}{*}{ Total } & \multirow[t]{2}{*}{ Mean } \\
\hline & 1 & 2 & 3 & 4 & 5 & & \\
\hline Planning & 2.94 & 3.33 & 3.94 & 3.64 & 3.42 & 17.27 & 3.45 \\
\hline Setting & 3.97 & 3.42 & 2.97 & 3.39 & 3.45 & 17.2 & 3.44 \\
\hline Result & 2.42 & 3.58 & 3.09 & 3.39 & 2.94 & 15.42 & 3.08 \\
\hline Mean Variabel & & & & & & & 3.33 \\
\hline
\end{tabular}

The state of the employee performance variable can be described by the mean score of 3.33 which, if connected with table 3.3, the score is in the interval 2.51-3.50 with the criteria of being quite good and functioning quite well. The state of the performance variables can be interpreted that the civil servants' performance is categorized as quite useful and functions quite well in carrying out their duties as state civil apparatus.

Three dimensions in each performance variable are the planning dimension with a mean score of 3.45 , the implementation dimension with a mean score of 3.44, and the outcome dimension with a mean score of 3.08 which, if referred to in table 3.3 , is in the interval $2.51-3.50$ with the criteria of a reasonably good condition and functioning adequately.

\section{Inlfuence Test of Competence Variables $\left(\mathrm{X}_{1}\right)$ on Performance Variables $(\mathrm{Y})$}

The results of the calculation show that the correlation coefficient $r$ between the competence and the performance variable of the state civil servants is 0.7252 . This value, if connected to table 3.2 , is in the interval $0.60-0.799$, meaning that the influence of competence on the performance of the state civil apparatus at Wewiku district, Malaka regency is vital. The strong influence between the two variables can be interpreted that the better the competence of the state civil apparatus, the better the performance of the state civil apparatus in Wewiku district, Malaka regency.

\section{Influence Test of Discipline $\left(\mathrm{X}_{2}\right)$ on Performance Variables (Y)}

The result of the calculation shows that the correlation coefficient $r$ between the discipline and the state civil servant performance variable is 0.6487 . This value, if connected with table 3.2 , is in the interval $0.60-0.799$, means that the effect of discipline on the performance of the state civil servants in Wewiku district, Malaka regency is vital. The strong influence between the two variables can be interpreted that the better the competence of the state civil apparatus, the better the performance of the state civil apparatus in Wewiku district, Malaka regency.

\section{Influence Test of Competence $\left(X_{1}\right)$ and Discipline $\left(X_{2}\right)$ on Performance $(Y)$}

The results of the calculations using the regression equation for two predictors are as follows: If $Y=a+b_{1} X_{1}+b_{2} X_{2}$, the Adjusted R Square value of 0.60757 multiplied by $100 \%$ will result in $60.759 \%$, meaning that the influence of competence $\left(\mathrm{X}_{1}\right)$ and discipline $\left(\mathrm{X}_{2}\right)$ on the performance of state civil apparatus in Wewiku district is quite significant. Therefore, the effect of the two variables on the above performance shows that there are $39.241 \%$ of other variables not studied yet. Accordingly, the influence of the competency variable on the performance of the civil service had a p-value of 0.00025199 . The $p$-value is less than 0.05 , which means that there is a significant influence of the competence variable on the performance of state civil servants in Wewiku district, Malaka regency. Likewise, the influence of the discipline $\left(\mathrm{X}_{2}\right)$ on the performance of state civil servants in Wewiku district, Malacca regency with a p-value of 0.0062294 means that the effect of the discipline on the performance of the state civil apparatus in Wewiku district, Malaka regency is quite significant. 


\section{CONCLUSION}

1. The influence of competence on the performance of state civil servants in Wewiku district, Malaka regency is strong. The strong influence between the two variables can be interpreted that the better the competence of the state civil apparatus, the better the performance of the state civil apparatus in Wewiku district, Malak regency.

2. The influence of discipline on the performance of state civil servants in Wewiku district, Malaka regency is strong. The strong influence between the two variables can be interpreted that the better the discipline of the state civil apparatus, the better the performance of the state civil apparatus in Wewiku district, Malaka regency.

3. The effect of competence $\left(\mathrm{X}_{1}\right)$ and discipline $\left(\mathrm{X}_{2}\right)$ on the performance of the state civil servants in Wewiku district is quite significant.

4. The influence of competence on the performance of the state civil servants results in a p-value of 0.00025199. The p-value is less than 0.05, which means that there is a significant influence of the competence variable on the performance of state civil servants in Wewiku district, Malacca regency.

5. The influence of the discipline $\left(\mathrm{X}_{2}\right)$ on the performance of state civil servants in Wewiku district, Malaka regency with a p-value of 0.0062294 means that the effect of the discipline variable on the performance of the state civil apparatus in Wewiku district, Malaka regency is quite significant.

6. Based on the results of the mean analysis, it is concluded that the state of the competence, discipline, and performance variables of the state civil servants in Wewiku district, Malaka regency is quite good and functions quite well.

7. Based on the multiple regression analysis, it is concluded that 39.241 other variables have not been studied to measure their effect on the performance of the state civil servants in Wewiku district, Malaka regency.

\section{SUGGESTION}

1. The influence of the competence and discipline variable on the performance of state civil servants in Wewiku district, Malaka regency has only reached $60.759 \%$. Therefore, the head of Wewiku district and the Regent of Malaka regency is recommended to further improve employee competence and discipline by conducting further studies for civil servants, registering employees in training, and fostering employee attitudes so that they have a more positive effect on the performance of the state civil apparatus.

2. There are still $39.241 \%$ of other variables that are likely to influence the performance of the state civil servants that have not been researched so recommendations are formulated to academics to conduct a study on various other variables that are likely to have an influence on employee performance.

3. Thus, the Regent of Malaka regency can improve the performance of the state civil apparatus by implementing a system of individual and institutional reporting on a weekly and monthly basis so that it can spur work activity for each state civil apparatus.

\section{REFERENCES}

1. Handoko, T. (1994). Manajemen personalia dan sumber daya manusia. Yogyakarta: Liberty.

2. Mahmudi. (2005). Manajemen sektor publik. Yoykarta : Akademi Manajemen YKPN

3. Mangkunegara. (2005). Evaluasi kinerja sumber daya manusia. Bandung: Refika Aditama..

4. Mashun, M. (2006). Pengukuran kinerja sector publik. Yogyakarta: badan penerbit FE UGM

5. Moenir, H. A. S. (2008). Manajemen pelayanan umum di indonesia. Jakarta: Bumi Aksara

6. Moekijat. (1999). Manajemen sumberdaya manusia manajemen kepegawaian. Bandung: Mandar Maju.

7. Pasolong. H. (2008). Teori administrasi publik. Malang: In-Trans

8. Tim Penyusunan Depdiknas. (2001). Kamus besar bahasa indonesia. Jakarta: Balai Pustaka

9. Undang - Undang Republik Indonesia Nomor 5 Tahun 2014 Tentang Aparatur Sipil Negara.

10. Yuniarsih.T dan Suwatno, (2008). Manajemen sumber daya manusia: teori, aplikasi dan isu penelitian. Bandung: Alfabeta. 